\title{
Deities and Spirits in Andean Belief - Towards a Systematisation Sabine Dedenbach-Salazar Sáenz
}

To be published in Anthropos 112/2 (2017) (Pre-publication version, 1 October 2017).

\begin{abstract}
$\underline{\text { Abstract }}$
Most people who live in the rural Andes have considered themselves Christians for several hundred years, and their religion combines traditions of Andean and Christian origins. In order to understand the basic concepts of life in the Andes I will study the deities and spirits who inhabit nature and how they affect human beings. Apart from major deities (Pachamama, the Apus) there are other beings, the spirits: dangerous and evil ones hovering in liminal space and time as well as benevolent ones who help the deities. By systematising materials and studies from Peru, I will show that, although words and certain concepts are blended in what may be called Andean Christianity, the (super)natural world is essentially Andean.
\end{abstract}

Key words:

Andes, Quechua, 20th century, religion, deities, spirits, Christianisation, cultural blending

\section{Biographical note}

Sabine Dedenbach-Salazar Sáenz is Senior Lecturer at the University of Stirling (Scotland, UK). Her interests centre on the ethnolinguistics, anthropology and ethnohistory of the Andean languages, esp. Quechua, and which role these have played in the Christianisation process. (Email: sd39@stir.ac.uk, sdedenbach@hotmail.co.uk; Internet: http:/www.dedenbachsalazar.stir.ac.uk; http://rms.stir.ac.uk/converis-stirling/person/11643; http://www.translatingchristianities.stir.ac.uk; http://www.crossingcultures.stir.ac.uk.)

The corregidor as dragon and the encomendero as lion: symbolic language to depict antisocial behavior in Guaman Poma's Andean colonial world. Language Typology and Universals (STUF - Sprachtypologie und Universalienforschung), Special Issue: A Colonized World Revisited: Linguistic Perspectives from Unpublished Colonial and Postcolonial Documents (Astrid Alexander-Bakkerus and Otto Zwartjes, eds.), vol. 67, no. 2: 149-173. Berlin 2014. (< http://hdl.handle.net/1893/22247 > [accessed 11.07.2017].)

Don Cristóbal, Llocllayhuancupa and the Virgin: The battle of words in a colonial quechua conversion narrative. In: James L. Cox (ed.), Critical Reflections on Indigenous Religions, pp. 105-122. Farnham: Ashgate 2013. (Vitality of Indigenous Religions.)

Muchay - worshipping God and the huacas: The complex usage of a Quechua word in the colonial Andes. In: Susana Bayó Belenguer; Eiléan Ní Chuilleanáin; Cormac Ó Cuilleanáin (eds.),Translation Right or Wrong; pp. 173-190. Dublin: Four Courts Press 2013.

"Our grandparents used to say that we are certainly ancient people, we come from the chullpas": The Bolivian Chipayas' mythistory. Oral Tradition 27/1: 187-230. < http://journal.oraltradition.org/issues/27i/dedenbach-salazar_saenz > (accessed 11.07.2017). 


\section{Introduction}

In this study I will present some essential concepts of the perception of the Andean natural world and its interpretation in spiritual terms and use examples to illustrate how these interrelationships with nature work. The questions I raise and which I see as a basis for further discussions are how far these phenomena can be systematised, where Andean and Christian influences are detectable and how this can be interpreted. ${ }^{1}$

The Andean highlands ${ }^{2}$ are inhabited not only by humans and animals, but also by many other beings, powerful and dangerous. The mountain deities, the Apus, and the 'WorldMother', Pachamama, occupy dominant positions in the natural environment which determines people's lives and destiny. The basic relationship with them is that of reciprocity and complementarity ${ }^{3}$, essential to guarantee personal and social wellbeing. Apart from these deities a large number of spirits, most of them malignant or at least dangerous, live in the Andean mountains. Although I will refer to the deities and the spirits as supernatural beings, in the Andes no clear distinction is made between what we call religion and the secular - life is considered a unity, determined by human and spiritual forces.

Christianity was taught from the very beginning of the colonial era in Quechua and other indigenous widespread 'general' languages ${ }^{4}$, mainly through the translation of the catechism,

The data are mainly from late 1960s and 1970s Quechua-speaking Southern Peru. This was the period when most studies were published; more recent work is sporadic, but shows that little has changed. Much of what has been written about these beings was in the framework of a Christian understanding and mission, by anthropologists many of whom were also Catholic priests; most of these writings were published in the journal Allpanchis. It is interesting to observe that the writings of the Catholic missionaries-anthropologists do not categorise Andean religious beliefs and practices as inferior to Christian ones, but are mainly descriptive within a 'neutral' framework. The narrations from Southern Peru, some folk narratives, others descriptive accounts, by the indigenous villagers of Pinchimuro in Kay Pacha (Gow and Condori eds. 1976) as well as the narrations made by Délétroz' (1993) consultants in Coaza balance and largely confirm this information. There are also many folk stories whose characters and events centre on these spirits and their interactions with human beings (for example Payne 2000: 201-249 for dangerous beings, such as condenados; 251-271 for helping spirits). For a brief summary see Marzal (1996: 83).

2 The Andean countries (Ecuador, Peru, Bolivia) comprise an ecologically and culturally complex area which consists of vertical micro-climatic zones where human settlements reach from sea level to 4,800 $\mathrm{m}$ altitude. The common traits of traditional highland culture are a highly developed agriculture with terraces and irrigation systems (maize, potato, quinua) and animal domestication and breeding (llama, alpaca, guinea pig), complemented by European products and animals. (For descriptions of Andean ecology see Pulgar (1996) and Gade (1999, ch. 2, esp. pp. 36-38.)

3 Family and territorial groups (ayllus) are the basic units of social organization. An ayllu can range from a relatively small kingroup to a whole social unit such as a village or district and can be defined by access to land or common descent (see Allen 1988: ch. 3). Interpersonal and social relationships within the ayllu are characterised by complementarity and reciprocity (ayni). This refers to the sharing of work among family members and neighbours which is repaid in kind (ibid. 92-94).

4 Today's official language is Spanish which was brought to the Andes by the 16th century conquerors. Of the many indigenous languages only Quechua (ca. nine million speakers), Aymara (ca. three million speakers), Chipaya (ca. 1200 speakers) and Jaqaru (ca. 740 speakers) are spoken in the Andean highlands at present (cf. Lewis et al. 2015: https://www.ethnologue.com/language/que; https://www.ethnologue.com/language/aym; 
sermons, confessionaries etc. The result of the cohabitation of Christian and Andean religion is what has been called 'Andean Christianity' and formulated in an 'Indian Theology'. ${ }^{5}$ When the Andean countries became independent from Spain at the beginning of the 19th century, the influence of the Catholic orders, which had dominated the conversion and religious life, decreased, and in many cases the secular clergy took over; ${ }^{6}$ and although there is an increasing influence of Protestant churches, despite many economic changes and political upheavals the Latin America countries have remained largely Catholic. ${ }^{7}$ It is in this context that contemporary Andean belief has developed.

\section{Divine Beings: Apus, Pachamama, Patron Saints and the Christian God}

The highest mountain peaks are inhabited by beings who are imagined as endowed with divine power: these Apus communicate with humans and are conceived of as behaving like them; they are creators and at the same time reflect the human social order and economic system. They are also related to the ancestors; they can take the shape of animals or human beings and in this way interact with other mythical beings and humankind. Thus, for example, the Apu in form of a condor may talk to people through a religious specialist. ${ }^{8}$

Whilst the Apus can be considered localised deities, Pachamama is rarely imagined as a concrete person; her power is also firmly rooted in nature, but she is present everywhere therefore I see her as the principle of life rather than the 'World-Mother' (literal translation) or a specific deity. As the rituals carried out for her show, Pachamama is located beneath the earth in mountains, close to mines or in stones of certain shapes. She is often related to irrigation systems and springs, lakes and rivers as well as to mysterious grottoes or dangerous sites; she is also said to reside in pacarinas (from paqari-, 'to be born') which people imagine to be the ancestors' and herding animals' places of origin (Mariscotti de Görlitz 1978: 31-35, 57-84). The narrator of a story about Pachamama emphasises her productive force by using terms such as "kuyda", 'to take care of', and "uywa-" small children and animals'. She is alive: she has hair which is the pasture, and blood and milk flow inside her. He adds that she is really like our mother. It is important to respect her and work on her at the times due to her, otherwise her sadness and wrath may cause harm.

http://www.ethnologue.com/language/cap; https://www.ethnologue.com/language/jqr [all accessed 12.06.2016]).

For a summary of Andean religion see Marzal (1996) and Albó (1996). Sallnow (1987) gives a sketch of the pre-Columbian Andes (ch. 2) and contemporary religious features (ch. 3, 4); also see Ricard (2007) for rituals and curing; Gose (1994) for the interrelation of religion and agriculture; and Gose (2008) for the historical and colonial angle. The teaching of the Christian faith in native languages is discussed in González and González (2008: 54-55) and Dedenbach-Salazar Sáenz (2008: 35-36). On the 'teología india' see Irarrázaval (1996) and Gorski (1996).

6 Cf. Andrien (2001: 84-190).

7 For a history of the Catholic Church and Protestant Churches see González and González (2008: ch. 5-10).

$8 \quad$ The Huarochirí Manuscript ([ca. 1608] 1991), e.g. ch. 2 and 5 and passim, for myths about pre-Spanish times. For contemporary sessions of communication see Casaverde (1970: 214 218) and Platt (1997).

9 I use the official orthography for the Peruvian Quechua dialect as established in 1975, but with three vowels (Cusihuamán 1976: 35-52; Valderrama and Escalante 1992) and pluralise nouns with an English '-s'. Literal quotations maintain the particular spellings of the authors. 
The same consultant makes it clear that she herself does not bring bad luck to people, but she warns them (Gow and Condori eds. 1976: 10-12).

In folk belief it was obvious to connect Pachamama and the Virgin Mary; both are seen as symbols of human fertility as well as responsible for that of crops and animals. This parallel is evident in many apparitions of the Virgin in Spain in the 16th century, some of which go back to the Middle Ages. Where such an apparition or image occurred - often to a poor farmer - a shrine would be built. The places used to be at rarely visited sites, such as mountains, caves or wells. ${ }^{10}$

In addition to these Andean powerful beings, since colonial times every community has a patron saint, often in form of the mythical revelation of Christ or a saint as the 'Lord of ...' or the Virgin or a saint as 'the Lady of ...'. The saints would first appear miraculously and have become the protectors of the community which celebrates them once a year. ${ }^{11}$ The most important regional festival in Peru is that of the Lord of Qoyllur Rit'i ('Star Snow'), where several thousand people from a wide area come together for Holy Trinity Tuesday to make a pilgrimage to the mountain peak of Ausangate. The celebrations include traditional indigenous dances as well as the veneration of Christ at the chapel and culminate in bringing down pieces of ice - evidence of the blending of Christ and the Apu. ${ }^{12}$

It is not only typical of Latin America, but also of Spain, that the saints are closely related to native or folk religion (Dedenbach-Salazar Sáenz 2013b) and, like God, can be seen as deities (rather than orthodox intermediaries) who have considerable influence on people's personal and social life.

Meteorological phenomena, such as hail, chiqchi, snow, rit'i, and lightning, qhaqya (Illapa in Inca times), and the celestial bodies, especially the sun, inti, and the moon, killa, were all major wakas ${ }^{13}$ in Inca times and are still present in contemporary Andean faith, but are less important in their influence than the Apus and Pachamama (Núñez del Prado 1970: 94-98).

The Christian God is part of the Andean pantheon, but people have different conceptions of him. He is seen as creator and almighty, but also as an invisible spirit. He may appear as an old man in rags to test people's faith and cause earthquakes to punish them. However, more often than an active deity he is a deus otiosus, although his punishment of disrespectful or disobedient people reminds us of the Andean deities described in an early colonial document who did the same. ${ }^{14}$ The deity's punitive reaction can be seen as a characteristic of reciprocity in Andean religion, but it also reminds us of the God of the Old

10 See Dedenbach-Salazar Sáenz (2013b: 166-167, 188).

11 Casaverde (1970: 126-132); cf. Marzal (1996: 71-77, 96-97).

12 Sallnow (1987: 228). In 2011 the pilgrimage was included in the "Intangible Cultural Heritage of Humanity" (UNESCO 2011).

13 A waka can be any element or feature found in nature and considered to have particular force and power, referring to both the physical manifestation of the supernatural force (e.g. a mountain peak, a stone) and the force or being itself, either as an abstract concept of a numinous being located in these features of nature, or a man-made object representing it (e.g. a statue). In pre-hispanic times some wakas were important oracles.

14 According to the consultants of Marzal (1970: 37-38). The Huarochirí Manuscript ([ca. 1608] 1991): Cuniraya, ch. 2, pp. 46-48, and Huatyacuri, ch. 5, p. 56; New Jerusalem Bible ([s.a.] 1985): Genesis, ch. 6 (the deluge): http://www.catholic.org/bible/book.php?id=1\&bible chapter=6; ; ch. 19 (Sodom): http://www.catholic.org/bible/book.php?bible chapter=19\&id=1 repectively (both accessed 11.07.2017). 
Testament whom the colonial missionaries portrayed as wrathful. ${ }^{15}$ Thus the contemporary image of God may well be influenced by Christian missionary teaching and Andean traditions. On the other hand, in the Andes Christ is not a central part of the reciprocal system and is conceived of as a deity of justice and may be invoked as such, but he is not always part of the Christian Trinity. Depending on the characterization people will give of God and Jesus, they sometimes have traits of a trickster. ${ }^{16}$ There are also different perceptions of the Holy Ghost. In Chuquisaca (Bolivia) he is a saint with his special festival day; he works miracles and (not unlike a Guardian Angel) protects people (Wrisley 1973: 162-164).

The distinctive nature of all the deities and of Pachamama is their ambiguity: they can be benevolent, but when not treated respectfully they can become angry and wrathful and cause people to fall ill or a community to suffer a natural disaster. Therefore, within the Andean conception of reciprocal interaction (ayni), people communicate with them, often with the help of specialist intermediaries and through offerings. And although the mountain spirits and Pachamama received Christian counterparts in the saints and the Virgin, their basic role in life has remained Andean.

\section{Spirits}

Besides the mentioned supernatural beings or deities there are also spirit-like beings that populate the Andean world.

I understand spirit ${ }^{17}$ as an entity which can be described, as Jung put it, as a substance, a dynamic principle, alive, a breathlike presence, and although as such disembodied, it lends itself to personification (Jung [1945] 1954: 5-8). In the Andes it can manifest itself as a physical being: a re-embodied entity which is not good or evil as such. Andean spirits are 'liminal' ${ }^{18}$ as they do not live in the space and present time defined by and for humans, i.e. houses, villages, cultivated fields etc., but dwell in places which are not clearly assigned to human activities, and they can also be related to another era. People meet liminal spirits when they cross the threshold from social space and present time to that 'in between' which lies beyond 'civilization' and culturally accepted spheres.

15 The Lima Council's 20th sermon, for example, warns the indigenous parishioner (in Quechua) that the liar will go to hell and burn in its fire forever (Tercero cathecismo [1585] 1985, p. 588 / fol. 120v).

16 See for example the story about "Child Jesus, Yarn Spinner" (Payne 2000: 263-271).

17 Already in early European translations of Christian texts from around $400 \mathrm{AD}$, in the concept of the Trinity the Germanic word 'Geist', 'spirit', was used although it had "considerable preChristian supernatural significance, meaning the essence of the departed" (Murdoch 2016). The Devil as a fallen angel incorporates the ambiguity of an 'evil' spirit (cf. Jung [1945] 1954: 9). Thus 'spirit' can include both the spirit as liminal being, but also the Holy Spirit as a kind of divine essence. This shows how the concept went through different cultural adaptations and modfications, but spirits in Europe and in the Andes can share liminal, disembodied and reembodied attributes. Therefore the word 'spirit' is the most adequate one to be used in this context.

18 Since its coinage by van Gennep in his theory on the rites of transition, liminality has become widely applied in different contexts and is characterised by spatial and temporal dimensions (Thomassen 2009: 16-17). 


\subsection{Liminal Spirits: Ambiguous, Dangerous and Evil Beings}

Whilst the Apus, Pachamama and the saints can be benign or harmful, depending on human behaviour towards them, these liminal spirits are unhappy and can therefore cause illness and death. People meet them when they come close to their space, such as rivers or graves. Rather than communicating with them, as is done with the Apus and Pachamama, one tries to avoid them so as not to come to harm, although occasionally offerings are made to placate them (Gow and Condori eds. 1976: 68).

For example, the sirenas - not unlike the Western sirens - reside in wet places, under waterfalls or in rivers and attract people with their songs; humans will then be enchanted by them and get lost in an unknown world, fall ill or even die. On occasion musicians will leave their instruments in the sirenas' places so that they can be tuned by them. In some folktales the sirena is also a helping spirit. ${ }^{19}$

In some communities the sirena is equated with the saqra, a being related to the shadowworld and the ancestors and sometimes used as a synonym for supay; neither of them was traditionally related to evil, but the Devil of Christianity is translated as supay. ${ }^{20}$

Whilst the sirena seems to be of ambiguous character, other spirits are conceived of as purely harmful.

The European duende, which can be translated from Spanish as 'goblin' or 'demon', was said to infest houses. ${ }^{21}$ In its Andean understanding it is the child who died before being baptised. A connection to the Spanish meaning could be that the Andean duende, like the European, is a small being set on causing mischief or even major problems. ${ }^{22}$ Casaverde's consultants described the duendes they had encountered as small persons who in one case caused the narrator a boil which could only be healed by a specialist; in the other case the duende loosened the ground causing a landslide. ${ }^{23}$ Like sirenas, they are often related to water. I consider their spaces liminal because they are conceived of as the threshold to the world inside or below, ukhu pacha. ${ }^{24}$

As we have seen, certain European elements are present in some spirits, but others are firmly rooted in Andean belief. The machu ancestors reside in house- or tower-like structures, the gentiles wasis ('ancestor houses') or chullpas and can, for example, cause harm to children who play close to them. The wind of the ancestors, machu wayra or suq'a wayra, can cause illness, and those affected have to be cured by a paqu (a healing specialist). One of the illnesses caused by them is called susto, 'fright', also known in Spain,

19 Casaverde (1970: 175); Michaud (1970: 13); Payne (2000: 251-261); in one tale it is made explicit that good spirits appear to good humans whereas the evil ones to bad persons (ibid. 260-261). Cf. Ricard (2007: 130-135).

Cáceres (1970: 21-25). For a summary of the historical development of the concept see Dedenbach-Salazar Sáenz (2013a: 92-94).

21 Diccionario de Autoridades ([III/1732], 2/1976: 347).

22 Allen and Albó (1972: 55) document that the Aymara from Achacachi, Bolivia, believe that natural disasters can have their origin in that a child was aborted or died when not yet baptised.

23 Casaverde (1970: 176-179); cf. Núñez del Prado (1970: 94).

24 Sánchez (2006: 261) mentions mountain tops, lakes and springs as 'liminal points' between this world and the world below.

Ukhu pacha is part of a threefold concept which also includes kay pacha, 'this world (space and time)', and hanaq pacha, 'the world above' (due to Christian influence equated with heaven) (see Casaverde 1970: 207-210; cf. Marzal 1996: 85). 
which in the Andes has its origin in the theft of the person's soul (anima). ${ }^{25}$ Other malignant influence comes from the suq'a beings - the male suq'a machu and the female paya machu who cause illness due to sexual wrong-doings of the victim. ${ }^{26}$

The souls of the dead, alma, roam for a long time, but only those who committed incest or another serious crime, appear as condenados who can cause illness or death for those who meet them. ${ }^{27}$ It is interesting to note that condenados often reside in high mountain areas (Fourtané 2015: 119-124) and are therefore somehow related to the Apus; not unlike a possible connection of the sirenas with Pachamama - both inhabit liminal spaces. Usually at night and often personified as women, condenados are mostly encountered by other sinners. ${ }^{28}$ It becomes clear that the term is taken from Spanish, and possibly some of the meaning flowed into what must also have been an Andean perception, a phenomenon which I suggest calling convergence Dedenbach-Salazar Sáenz 2013b: 162).

However, not all the spirits who are present in dangerous places are manifest in physical beings who appear to a person. Sometimes it is the effect they can have which makes people believe that a dangerous spirit resides in a feature of the natural environment, for example in the case of the anchanchu that caused pastures to be so boggy that animals would die there, or the river, elemento, which made a person sick when he fell over in it and thereby 'disturbed' it (Gow and Condori eds. 1976: 68, 69).

These examples may suffice to show that the spirits - although not always malignant as such - tend to cause harm when one happens to meet them. Only offerings to the Apus and Pachamama can undo this damage.

Baer et al. (2006: 142); Michaud (1970: 15-16); Núñez del Prado (1970: 88-89).

26 Núñez del Prado (1970: 83-87). Machu, 'old man', paya, 'old woman'; suq'aya- means 'to become malignant or harmful' and is derived from the verb suq'a-, 'to beat' (Lira 1945: 924925). The suq'a pukyu, 'malignant spring spirit', can cause respiratory disease. Possibly Western and Andean influences come together in the water-related spirits, the mentioned sirena and the suq'a pukyu.

27 In ancient and contemporary Spain the soul of a dead person who is in purgatory and has not yet arrived in heaven or hell is called alma en pena, whilst the condenado is codemned to hell (Fourtané 2015: 76). The Andean condenado is more similar to the alma en pena because he can be saved (ibid. 78, 219); sometimes the terms are used interchangeably (ibid. 88) reflecting a complex syncretism (ibid. 233).

In the teaching materials in Spanish, Quechua and Aymara published by the Church in Peru in the 16th century (and which were later reprinted and used for centuries), terms derived from condenar, incl. condenado, were frequently employed and refer to condemnation for one's evil deeds, based on any kind of sin (ibid. 214-215). It is therefore easy to understand how the word condenado and its negative meanings came to be part of the linguistic inventory of the Andes. It has to be pointed out in this context that the translation into Quechua omits the Spanish word and only says that the sinner will suffer forever or go to hell (Tercero cathecismo [1585] 1985, p. 395 / fol. 24r; p. 410 / fol. 31v; p. 741 / fol. 197r). Thus it seems that the Spanish word was used frequently, and through it Andean and Christian concepts became somehow connected.

The 'souls in pain' known in Spain are vagrant souls of the dead who can cause disturbances, but they are not, like those in the Andes, causes of disaster and death for the persons concerned (Erkoreka 1991; Fourtané 2015: 106-109). For how to pacify a condenado see Asunta's testimony (Condori and Quispe [1977] 1996: 121-123).

28 See Gow and Condori eds. (1976: 54-55); cf. Payne (2000: 199-206, 237-249). See Fourtané's comprehensive study on the condenado (2015). 


\subsection{Deities' Spirits: Protecting and Helping Beings}

Apart from the more ambiguous, but sometimes helpful sirenas there are only a few purely benign spirits. The angeles de la guarda, the 'guardian angels', are children who died when already baptised and protect human beings when they sleep. God makes guardian angels by forming them from clay (Cáceres 1970: 26). The other benign spirits are small invisible men and women who watch over the vicuñas (wild camelids valued for their wool); they are also called "inkas". ${ }^{29}$

Other spirits closely related to the Apus and the healer called altomisayuq are the parajes. In order to comprehend their role we have to understand that the Andean concept and practice of healing does not only refer to the curing of illness, but also in more general terms to (re-)establishing the balance between humankind and deities or spirits, which may have become upset by a person's misbehaviour or disobedience of social rules. ${ }^{30}$ Of the healing specialists, called paqus, the altomisayuq is the highest and most reliable person to consult because he can talk with the deities.

The text which will give us some information about a healing ritual and the role spiritual helpers play in it is the narration of a man who had witnessed how his father had become seriously ill with a deep-seated cough, a pulmon resfrio, 'cold of the lungs'; ${ }^{31}$ how his mother consulted several traditional healers; and how he was finally cured. ${ }^{32}$

The first healer the family consults thinks that the illness is caused by lightning and orders the man's wife to take a burnt offering to Apu Qanchinisu, the mountain deity. But the man becomes even more sick and his wife consults a second healer, a paqu. He rejects the first healer's interpretation, that 'evil air' which comes from the ancestors' graves must have caused the illness. According to him, what was only a deep-seated cold was treated in the incorrect way and thus the 'wrongly twisted thread of the spindle cannot be undone anymore'. ${ }^{33}$ However, he recommends the family to consult the highest-ranking healer, an altomisayuq. It is interesting to see that the altomisayuq despises the earlier consulted paqus as layqas, evil witches. Whilst the first two healers recognise that the mountain deity has to be addressed, it is only the third healer who engages in direct communication with the Apu. He has a canopy prepared in front of the door for the beings called parajes, and then he and the family wait for them. After expressing their anger that a witch had been consulted and not the altomisayuq, they order the family to buy and use certain remedies. At the end of

29 Aranguren (1975: 108). These may be related to the "enqaychus", wild animals or rocks in the form of animals which foster animal fertility (Núñez del Prado 1970: 90-92).

30 For Andean healers and curing practices see Casaverde (1970: 211-225); Núñez del Prado (1970: 104-106); Marzal (1971: 257-266); Garr (1972: 169-171); Gow and Condori eds. (1976: 71-80); Délétroz (1993: 27-35).

31 Heavy colds with complications were (and still are) common causes of illness, be they ascribed to 'normal' or 'supernatural' factors. In the 1960/70s the most frequent causes of death were '[evil] air', influenza and cough. (Christinat 1972: 76-77.)

32 The text was recorded by Leslie Hoggarth in the 1960s (Anonymous 2004). The narrator's parents lived in the province of Canchis, department of Cuzco, in Southern Peru.

33 A healer told Délétroz (1993: 29-30) that a witch can 'twist' one's life: 'When we notice that we are "twisted", spun by a witch, nothing we do moves forward' (transl. SDS; "Cuando nos encontramos 'torcidos', hilados por un brujo, nada avanza de lo que hacemos"), and a differently twisted thread of wool has to be used to undo this. 
three healing ceremonies the parajes show by dancing and ringing their little bells ${ }^{34}$ that they are content with the result.

In the narrator's words:

Hinaspa, chay paquqa

niwarqanku: "Kunallanmi,

parajekunata

suyayurqusunchis; punkuta

allinta tolderawan

antipuertarquychis; Diospa

partinmanta parajekunata

suyaykusunchis,

valeykusuntaq: icha hanpi

kashanmanraqpas".

...

Kinsa kaq kutinpiñataq

kutimullarqantaq; hinallataq

parajenkunapas chayamurqan

aswan kusisqaña.

Llapaykuta rimaykuwaspanku, vinonta tragontawan, kukatawan hallpaykurqan.

Chaypitaq kusikuymanta, campanillankuwan llapanku

chay parajekuna

tusuykurqanku kusikuymanta,

unquqpa qhaliyasqanmanta.
Then the paqu-healer said to us:

"Now let us attentively wait for

the parajes; we will carefully put

up a canopy in front of the door; on God's behalf we will wait for the parajes, and we will implore them: maybe there could even still be a remedy".

And he [the healer] returned a third time; then his parajes

arrived as well, very cheerfully.

Greeting us all, they chewed coca and took wine and liquor.

And there, joyfully, they all, the parajes, danced, with their little bells, very joyfully, because the ill man had recovered.

It is interesting that the narrator talks about the healer's parajes, but also about the parajes' healer. ${ }^{35}$ This shows that the relationship between the healer and his helping spirits is a very close one. At the same time it may imply that the parajes are manifestations of the Apu himself or that they act on his orders.

These parajekuna (literally Spanish 'place [in the landscape]' plus the Quechua plural marker -kuna) are what we may call place spirits. Other documented cases can help us gain a clearer picture of the communicative situation. Thus the Apus and Pachamama seem to

34 These remind us of the altar bells which are rung with consecration. Of course, bell-ringing is a universal apotropaic tradition; in Christianity in the Middle Ages bells were also used to deflect harm, e.g. caused by the Devil or natural disasters (Martí 2003: 311-312).

In an invocation of the Apus which accompanies an animal fertility offering, one Apu is addressed as "campanillayoq", 'owner of little bells' (Casaverde 1970: 146).

In an Aymara curing ceremony the healer suspends a little bell from the truss of the ceiling. During the following darkness the bell rings and a noise from the roof can be heard, as if a cat had jumped onto it, and a small voice starts speaking to the ones who are present. (Salazar 1972: 94.)

When quoting their conversation about the remedies which have to be bought, the narrator says: "hinallataq parajenkunapas chayamurqan", 'then his [the healer's] parajes arrived as well'; "chayta nispa, paquntañan rimaykuspa: ...", 'having said this, speaking to their paqu, they [the parajes] said: ...'. 
speak through the altomisayuq or appear in the shape of certain animals, for example a condor. $^{36}$ In this case the healer enlists helping spirits who may be manifestations of the $\mathrm{Apu}$ and help him to communicate with the deity. In a different context, a consultant interviewed by Ricard says that, in mythical times, they were the Apu transformed into a human being, and he uses the word paraje as a synonym for 'mountain': "Huq parajekuna, chay urqukuna runa kasqaku", 'The other parajes, those mountains, were people'. When Ricard says to him that the mountains can still nowadays transform themselves into condors in order to enter the altomisayuq's house, the interviewee answers: "Chay parajekunaqa huq kawsaq, ispiritiyuqsiyá kanku. Chayqa tukunkuman", 'Those parajes are living beings, it is definitely said that they have/own (a) spirit. Therefore they may transform themselves.' (Ricard 2003: 265; translation SDS). In an Aymara curing ceremony Salazar describes how the healer 'invoked the powerful mountain deities, the mountain deities that protect the house, and the places, to ask them for pardon', "hacía invocaciones a los achachilas, a los uywiris y a los lugares ${ }^{37}$ para pedirles perdón". ${ }^{38}$ Here again it becomes evident that the mountain is identified with the parajes.

However, there seems to me to be a difference between the transformation of the Apu in the mentioned descriptions and the appearance of the parajes in our narration. In the cases referred to above it is possible that the healer represents the Apu's voice and words and, in theoretical terms, can therefore be seen as a shaman operating in an altered or unusual state of consciousness and being possessed by a spirit. ${ }^{39}$ In the case of the parajes in our text it is more difficult to understand the spirits as an identification of the Apu and the healer as 'possessed by the spirit', because the narrator talks about them as beings that speak and dance, and he uses the narrative past employed for witnessed actions and events. Thus the healer seems to be an intermediary between the people and the parajes, who are the Apu or sent by him. However, one should not forget that spirit possession is a social phenomenon rather than a solely personal one and completely different from the experience a Westerner may have, and that what to us may need categorization, for the people involved in it is the manifestation of the deity in different ways. ${ }^{40}$

What is clear is that, in contrast to most other spirits I presented above and who are of threatening and malignant nature, these parajes are benevolent and helpful, either intermediaries between the healer and the deity or a manifestation of the deity itself.

Thus, what makes the benevolent spirits different from the other ones is that they do not belong to an unhappy person or hover in liminal space or time; rather they are protectors sent by divine beings or even represent them. The angeles de la guarda are God's, the vicuña-protecting inkas are apparently related to the ancient kings, and the parajes to the $\mathrm{Apu}$. Therefore the benevolent spirits are different in their character and relationship to humans and they are identified or at least closely related with divine beings.

\footnotetext{
36 Casaverde (1970: 214-218); Ricard (2003: 265/268); Platt (1997).

37 Spanish 'lugar' is a synonym for 'paraje'. For the Aymara terminology see van den Berg (1985: 11, 198).

38 Salazar (1972: 90-99, quote p. 92).

39 Crapanzano (1987: 12); see Platt's interpretation (1997: 200-201).

$40 \quad$ Crapanzano (1987: 14); Salazar (1972: 96-99) for the importance of the family in the curing session in the Andes.
} 


\section{Andean Religion}

\subsection{Deities and Spirits}

We have seen that most spirits are best avoided. Seemingly without motive they can cause harm, although this is often explainable through the human beings' inadequate behaviour when they have, for example, transgressed certain taboos or invaded their space. The Apus and Pachamama are different from these spirits in their dimension of power and the intentional and direct communication humans have with them. Moreover, the spirits are hardly ever addressed in offerings and prayers, but the deities and Pachamama are asked to undo the harm the spirits may have caused. Whilst the deities are related to prominent features of nature and landscape and to social groups, the liminal spirits are linked to particular features of the land or to certain individuals, for instance, the sirena to a river and the condenado and the duende to dead persons. However, some spirits have a connection to the deities, i.e. the space they inhabit is connected to that of the divine beings: Pachamama is linked to water and humid places, and so are the sirenas; the Apus and minor mountains, the awkis, evoke the ancestors called awki (Lira 1945: 72), and the suq'a spirits seem to be linked to those.

Due to their power which is conceived of as larger than that of the Christian almighty God in orthodox Christianity, the Apus and Pachamama are often blended with saints or at least integrate certain aspects of them in their behaviour: they are deities who influence human personal and social life.

The spirits, on the other hand, are mostly dangerous liminal beings or in some cases they are benevolent: they are forces which influence and determine human life. They are related to the deities because the dangerous ones can be pacified when the religious specialist calls on higher beings, and the benevolent ones assist the divine powers. They are spirits in the sense that they are manifest either as a 'breathlike disembodied' presence or they are reembodied in physical beings, such as a white-clad condenado woman or a duende in the shape of a small person.

What deities and spirits have in common is the harm they can cause to human beings. They affect a person or society in the form of illness, misfortune, death or disaster. The underlying cause can be, in case of the deities, a person's carelessness or lack of respect; in case of the spirits transgressing taboos or committing crimes. What has to be done in almost any case in order to mitigate these effects and restore personal wellbeing or social balance is the communication with Pachamama or the Apus, bringing them offerings.

\subsection{Blending Words - Blending Cultural Practices?}

Whilst it is obvious that the century-long cultural blending and hybridity is responsible for amalgamations on the conceptual as well as expressive level, it is impossible to find out the exact underlying historical processes. Their complexity is reflected in the language used. In most cases a Spanish term does not necessarily imply a Christian meaning or may only remind us of a Western origin, as is the case, for example, in the names for the spirits called duende or condenado: underlying Christian meanings were blended with Andean ones and with Spanish regional folk meanings, giving an Andean concept a Spanish name (which may vary in different places).

In his analysis of the Southern Peruvian terms for rituals Albó suggests different explanations for the usage of Spanish words; one is a possible 'camouflage' which may help to explain these phenomena (Albó 1996, esp. p. 270). This, which I would even call 
subversion $^{41}$, may have been a reaction in colonial times when the extirpation of idolatry campaigns persecuted and prohibited the practice of the indigenous faith ${ }^{42}$. As seen in the above examples, the Andean population adapted Spanish terms to an essentially native phenomenon, or indigenous terms were filled with Christian meanings, probably first by the missionaries who tried to convert the indigenous people by using their native languages. Consequently the incorporation of Christian phenomena into the Andean faith is found in practices, such as dances, and in theological concepts, for example Pachamama as a Trinity of "Pacha Tirra, Pacha Nusta, Pacha Virgen", ${ }^{43}$ manifesting herself not only as a multiple deity but also as incorporating Andean, Inca and Spanish time. The result is a specific Andean religious terminology which reflects the presence of both beliefs. However, although some phenomena have received Christian denominations, in terms of their meaning and significance they remain essentially Andean. Thus in the case of the deities and Pachamama, there is an inclusion of Christian saints into the Andean cosmological conception. The condenado is a life-threatening Andean dead person rather than a soul going through purgatory. In very few cases the Catholic necessity to translate a Christian concept has led to a change in the meaning of the Andean one, for example supay, a being related to the ancestors and the shadow world, has become the Devil. It also occurs that Christian concepts, like that of the angel de la guarda, acquire features where they become helping spirits of the deity. The majority of phenomena, however, have either kept their native denomination (like the ancestor machu spirits) or have superimposed a Spanish term on what has remained an Andean concept, as we can see in the case of the parajes whose only relation to Christianity is their name, possibly the bells they ring and the fact that the healer calls on them 'on behalf of God', "Diospa partenmanta" 4 , but on the whole the healing ritual is close to a shamanic one ${ }^{45}$. As part of the communication with the Apu and 'his' parajes or with Pachamama, the system of healing rituals has essentially remained indigenous.

In all cases these concepts are testimony of several hundred years of contact with Christian religion. Sometimes orthodox belief was incorporated in a concept and blended with different stories, as with the mentioned guardian angels. More often, though, it must have been the influences of popular culture brought to the natives by Spanish merchants, soldiers or barbers - 'simple' folk ${ }^{46}$ who almost certainly believed in phenomena which the Church called superstition ${ }^{47}$.

41

42

43

44

46

Cf. Dedenbach-Salazar Sáenz (2013a: ch. 5.5).

Gareis (1999); Mills (1997).

Gow and Condori eds. (1976: 10); Quechua pacha, 'world', ñusta, 'Inca princess'; Spanish loans tirra, 'tierra', 'earth', virgen, 'virgin'.

This reminds us of Marzal's referral to the altomisayuq being struck by lightning on behalf of God (1971: 258).

See an overview of shamanism by Eliade (1987). Platt (1997: 202-203, 224) shows how in the case of the session he witnessed the European form of legal and administrative organization has been carried into what he terms the 'shamanic' session.

Although for administrative (and ideological) reasons the Spaniards established a 'republic of the Indians' and another 'republic of the Spaniards', there were many contact points between the indigenous people and the colonisers. These were especially evident in labour and economic relations; thus the Spanish created the encomienda (indigenous workforce 'entrusted' to a Spaniard) or the repartimiento de bienes (the forced distribution of goods) (cf. Andrien 2001), and numerous documents give details about the kind of mostly exploitative contact. Among the sources are, for example, the detailed documentation of inspections carried out for tax purposes (e.g. the 1567 Visita hecha a la provincia de Chucuito, 1964) and 
With respect to the deities, the system of reciprocity and complementarity has been maintained until the present: humans interact with the deities and expect that these reciprocate in order to keep or re-establish balance.

As far as some spirits are concerned, it is possible that their liminal and mostly dangerous character (only few are ambiguous like the deities) is due to the fact that at least some of them seem to be of European origin. They have intruded into the Andean way of communication, but not become an integral part of its reciprocity. Like the Europeans they are incalculable outsiders who have the power to cause damage when one does not take care. ${ }^{48}$ On the other hand, the place spirits have only received their name from Spanish, but remain closely associated with the indigenous healers and the Apus.

It is therefore evident that on the whole - although Christian beings or certain aspects of them have been integrated into Andean beliefs and practices - the basic tenets of the latter are still valid and show the integrative power they continue to have after almost 500 years of culture contact.

\section{References}

Albó, Xavier

1996 The Aymara Religious Experience. In: Manuel M. Marzal; Eugenio Maurer; Xavier Albó; Bartomeu Melià, The Indian Face of God in Latin America; pp. 119-167. Translated by Penelope R. Hall. [Original in Spanish: El rostro indio de Dios. Lima (Peru) 1991.] Maryknoll, NY: Orbis Books. (Faith and Cultures Series.)

1999 Entrecruzamientos lingüísticos en los rituales qullas. In: Sabine DedenbachSalazar Sáenz and Lindsey Crickmay (eds.), La lengua de la cristianización en Latinoamérica: Catequización e instrucción en lenguas amerindias / The Language of Christianisation in Latin America: Catechisation and Instruction in Amerindian Languages; pp. 249-276. Markt Schwaben: Saurwein. (Bonner Amerikanistische Studien / Estudios Americanistas de Bonn / Bonn Americanist Studies BAS 32; Centre for Indigenous American Studies and Exchange, St. Andrews, CIASE Occasional Papers 29).

\section{Allen, Catherine $\mathbf{J}$.}

1988 The Hold Life Has. Coca and Cultural Identity in an Andean Community. Washington and London: Smithsonian Institution.

\section{Allen, Guillermo and Javier Albó}

1972 Costumbres y ritos aymaras en la zona rural de Achacachi (Bolivia). Allpanchis 4: 43-68.

the accusations raised by the indigenous chronicler Felipe Guaman Poma de Ayala in 1615/16 (2001-04) about the colonisers (e.g. "the itinerant Spaniards on the royal road" [in ch. 21], "the chapter of the trustees of Indians, or encomenderos" [ch. 22] and "the chapter of censure, reprimand, and satirical dialogues" [ch. 26] - Guaman Poma de Ayala, El primer nueva corónica).

47 Castañega ([1529] 1946); Ciruelo ([1540] 1978).

48 The actions of other harmful beings refer explicitly to non-Andean malignant influence, for example the nak'aq, the 'slaughterer' (also wirachunchu, pishtaco; kharisiri, kharikhari in Aymara), sucks the bodyfat from a person and is often a foreigner or missionary (Michaud 1970: 15; Núñez del Prado 1970: 89-90; Briggs 1994) and has been interpreted as the "'racialized' outsider" (Canessa 2000: 705). 


\section{Allpanchis}

1969- Revista del Instituto de Pastoral Andina. Cuzco, Peru: Instituto de Pastoral Andina.

\section{Andrien, Kenneth $\mathbf{J}$.}

2001 Andean Worlds. Indigenous History, Culture, and Consciousness under Spanish Rule, 1532-1825. Albuquerque: University of New Mexico Press. (Series Diálogos.)

\section{Anonymous}

2004 Pulmon resfrio [1960s]. In: Leslie Hoggarth, Contributions to Cuzco Quechua Grammar, pp. 160-162. CD-ROM. Aachen: Shaker Verlag. (Bonner Amerikanistische Studien / Estudios Americanistas de Bonn / Bonn Americanist Studies - BAS 41.)

\section{Aranguren Paz, Angélica}

1975 Las creencias y ritos mágico-religiosos de los pastores puneños. Allpanchis 8: 103-132.

\section{Baer, Roberta D.; Susan C. Weller; Juan Carlos González Faraco; Josefa Feria Martín}

2006 Las enfermedades populares en la cultura española actual: un estudio comparado sobre el mal de ojo. Revista de Dialectología y Tradiciones Populares, vol. LXI, no. 1: 139-156. < http://rdtp.revistas.csic.es/index.php/rdtp/article/viewFile/5/5 $>$ (accessed 11.07.2017).

\section{Briggs, Lucy Therina}

1994 El $k$ "arik"ari en dos textos de lengua aymara: análisis morfosintáctico y del discurso. In: Margot Beyersdorff and Sabine Dedenbach-Salazar Sáenz (eds.), Andean Oral Traditions: Discourse and Literature / Tradiciones Orales Andinas: Discurso y Literatura; pp. 161-197. Bonn: Holos. (Bonner Amerikanistische Studien / Estudios Americanistas de Bonn - BAS 24.)

\section{Cáceres Olazo, Mariano}

$1970 \quad$ Apuntes sobre el mundo sobrenatural de Llavini. Allpanchis 2: 19-33.

\section{Canessa, Andrew}

$2000 \quad$ Fear and Loathing on the Kharisiri Trail: Alterity and Identity in the Andes. The Journal of the Royal Anthropological Institute vol. 6, no. 4: 705-720. < https://www.essex.ac.uk/sociology/staff/Publications.aspx?ID=124 $>$ (accessed 11.07.2017).

\section{Casaverde Rojas, Juvenal}

1970 El mundo sobrenatural en una comunidad [Kuyo Grande]. Allpanchis 2: 121243.

\section{Castañega, Martín de}

1946 Tratado de las supersticiones y hechicerías [1529]. Madrid: Sociedad de Bibliófilos Españoles. (Sociedad de Bibliófilos Españoles, segunda época, XVII.)

\section{Christinat, Jean Louis}

1972 La mortalidad en Chia (Puno) a través de los registros del concejo municipal. Allpanchis 4: 69-100. 


\section{Ciruelo, Pedro}

1978 Reprouacion de las supersticiones y hechizerias [Salamanca, 1540]. Introducción y edicion de Alva V. Ebersole. Valencia: Albatros Hispanofila.

\section{Condori Mamani, Gregorio and Asunta Quispe Huamán}

1996 Andean Lives. Ricardo Valderrama Fernández and Carmen Escalante Gutiérrez, original editors [edition in Quechua and Spanish, 1977]. Translated from the Quechua ... by Paul H. Gelles, and Gabriela Martínez Escobar. Austin: University of Texas Press.

\section{Crapanzano, Vincent}

1987 Spirit Possession. In: Mircea Eliade (editor in chief), The Encyclopedia of Religion; vol. 14, pp. 12-19. New York: Macmillan.

\section{Cusihuamán G., Antonio}

1976 Gramática quechua Cuzco-Collao. Lima: Instituto de Estudios Peruanos y Ministerio de Educación.

\section{Dedenbach-Salazar Sáenz, Sabine}

2008 Dictionaries, Vocabularies, and Grammars in Andean Indigenous Languages. In: Joanne Pillsbury (ed.), Guide to Documentary Sources for Andean Studies, 15301900; vol. I, pp. 235-264. Norman, Oklahoma: University of Oklahoma Press and National Gallery of Art.

2013a Entrelazando dos mundos: experimentos y experiencias con el quechua cristiano en el Perú colonial. Quito: Abya-yala.

2013b Pachamama and the Virgin Revisited: Coincidences and Convergences. In: Michael Marten and Katja Neumann (eds.), Saints and Cultural Trans-/Mission; pp. 159-200. Sankt Augustin: Academia Verlag. (Collectanea Instituti Anthropos 45).

\section{Délétroz Favre, Alain}

1993 Huk kutis kaq kasqa. Relatos del distrito de Coaza (Carabaya - Puno). Sicuani and Cusco, Peru: Instituto de Pastoral Andina.

\section{Diccionario de Autoridades}

1976 Diccionario de la lengua castellana ... por la Real Academia Española. [Madrid: Viuda de Francisco de Hierro, t. III, 1732]. Facsimile, vol. 2. Madrid: Gredos, 1976. (Biblioteca Románica Hispánica 5, Diccionarios 3.) [Original edition also at: $<$ http://ntlle.rae.es/ntlle/SrvltGUILoginNtlle $>(\text { accessed 11.07.2017). }]^{49}$

\section{Eliade, Mircea}

1987 Shamanism. In: Mircea Eliade (editor in chief), The Encyclopedia of Religion; vol. 13, pp. 201-208. New York: Macmillan.

\section{Erkoreka, Anton}

1991 Croyances à propos des âmes en peine au village de Bermeo (Biscaye). Hedatuz. Basque Culture and Science Digital Library - Cuadernos de Sección. Antropología - Etnografía 8 (San Sebastián): 23-32. < http://hedatuz.euskomedia.org/1696/1/08023032.pdf $>$ (accessed 11.07.2017).

\section{Fourtané, Nicole}

\footnotetext{
49 The books where the Internet site is indicated in square brackets are also accessible through the Internet, but I have consulted the print edition.
} 
2015 El condenado andino. Estudio de cuentos peruanos. Lima: Instituto Francés de Estudios Andinos (IFEA); Cusco: Centro de Estudios Regionales Andinos Bartolomé de Las Casas (CBC). (Travaux de l'Institut Français d'Études Andines 317; Centro de Estudios Regionales Andinos Bartolomé de Las Casas, Antropología 18.)

\section{Gade, Daniel W.}

1999 Nature and Culture in the Andes. Madison, Wisconsin: The University of Wisconsin Press.

\section{Gareis, Iris}

1999 Repression and Cultural Change: The 'Extirpation of Idolatry' in Colonial Peru. In: Nicholas Griffiths and Fernando Cervantes (eds.), Spiritual Encounters: Interactions between Christianity and Native Religions in Colonial America; pp. 230-254. Lincoln, Nebrasks: University of Nebraska Press.

\section{Garr, Thomas M.}

1972 Cristianismo y religión quechua en la Prelatura de Ayaviri. Cusco: Instituto de Pastoral Andina.

\section{González, Ondina E. and Justo L. González}

2008 Christianity in Latin America: A History. Cambridge: Cambridge University Press.

\section{Gorski, Juan F.}

1996 El fenómeno de la llamada 'Teología India'. Yachay (Cochabamba), año 13, no. 23: $75-98$.

\section{Gose, Peter}

1994 Deathly Waters and Hungry Mountains. Agrarian Ritual and Class Formation in an Andean Town. Toronto: University of Toronto Press. (Anthropological Horizons 4.) [Field data from 1981-83.]

2008 Invaders as Ancestors. On the Intercultural Making and Unmaking of Spanish Colonialism in the Andes. Toronto: University of Toronto Press. (Anthropological Horizons 36.)

Gow, Rosalind and Bernabé Condori (eds.)

1976 Kay pacha. Tradición oral andina. Cuzco: Centro de Estudios Rurales Andinos "Bartolomé de Las Casas". (Biblioteca de la Tradición Oral Andina 1.)

\section{Guaman Poma de Ayala, Felipe}

2001-04 El primer nueva corónica y buen gobierno (1615/1616) (København, Det Kongelige Bibliotek, GKS $22324^{\circ}$ ). Digitised edition, directed by Rolena Adorno and Ivan Boserup. Facsimile of the mansucript, transcription with critical annotations, bibliography and other materials. Copenhagen: The Royal Library. < http://www.kb.dk/elib/mss/poma/ > (accessed 11.07.2017).

\section{Irarrázaval, Diego}

1996 Trenzado de religiones: una aproximación a las vivencias y al diálogo interreligioso en una iglesia local. Allpanchis, año 28, no. 48: 81-106. 


\section{Jung, Carl Gustav}

1954 The phenomenology of the spirit in fairy tales [1945]. In: Olga Froebe-Kapteyn (ed.), Spirit and Nature. Papers from the Eranos Yearbooks, selected and translated from the Eranos-Jahrbücher, edited by, pp. 3-48. Translated from the German by R. F. C. Hull. [Zur Phänomenologie des Geistes im Märchen, in: Symbolik des Geistes, Zürich: Rascher Verlag, 1945.] Princeton: Princeton University Press, 1954 (second printing 1972). (Bollingen Series XXX-1.)

\section{Lewis, M. Paul; Gary F. Simons; Charles D. Fennig (eds.)}

2015 Ethnologue: Languages of the World. Dallas, Texas: SIL International, 2015. (18th edition.) $<$ http://www.ethnologue.com $>$ (accessed 12.06.2016).

Lira, Jorge A.

1945 Diccionario kkechuwa-español. Tucumán: Universidad Nacional de Tucumán, Departamento de Investigaciones Regionales. (Universidad Nacional de Tucumán, publicación no. 369, Instituto de Historia, Lingüística y Folklore, Sección Lingüística XII-2.)

\section{Mariscotti de Görlitz, Ana María}

1978 Pachamama Santa Tierra. Contribución al estudio de la religión autóctona en los Andes centro-meridionales. Berlin: Gebr. Mann Verlag. (Indiana Supplement 8.) [Internet: $\quad<\quad \underline{\text { http://www.iai.spk-berlin.de/en/publications/estudios- }}$ indiana/previous-volumes.html $>$ (accessed 11.07.2017).]

\section{Martí, Josep}

2003 Tierra: Los mitos y la música. In: Elisenda Ardèvol Piera and Glòria Munilla Cabrillana (eds.), Antropología de la religión: una aproximación interdisciplinar a las religiones antiguas y contemporáneas, pp. 275-324. Barcelona: Universitat Oberta de Catalunya. [Digital format 2014.]

\section{Marzal, Manuel M.}

1970 La imagen de Dios en Urcos. Allpanchis 2: 35-56.

1971 El mundo religioso de Urcos. Un estudio de antropología religiosa y de pastoral campesina de los Andes. Cusco: Instituto de Pastoral Andina.

1996 The Religion of the Andean Quechua in Southern Peru. In: Manuel M. Marzal; Eugenio Maurer; Xavier Albó; Bartomeu Melià, The Indian Face of God in Latin America; pp. 67-118. Translated by Penelope R. Hall. [Original in Spanish: El rostro indio de Dios. Lima (Peru) 1991.] Maryknoll, NY: Orbis Books. (Faith and Cultures Series.)

\section{Michaud, Andrée}

1970 La religiosidad en Qollana. Allpanchis 2: 7-17.

\section{Mills, Kenneth}

1997 Idolatry and Its Enemies. Colonial Andean Religion and Extirpation, 1640-1750. Princeton: Princeton University Press.

\section{Murdoch, Brian}

2016 Starting with the Goths: Translating Christianity across the Ages. University of Stirling, UK, unpublished munscript.

\section{New Jerusalem Bible [s.a.]}

1985 Joseph Henry Wansbrough (general editor). Bakersfield, Ca.: Catholic Online. < http://www.catholic.org/bible/ $>$ (accessed 11.07.2017). 


\section{Núñez del Prado Béjar, Juan Víctor}

1970 El mundo sobrenatural de los quechuas del sur del Perú, a través de la comunidad de Qotobamba. Allpanchis 2: 57-119.

Payne, Johnny (comp., transl. and ed.)

2000 She-calf and Other Quechua Folk Tales. Albuquerque: University of New Mexico Press.

\section{Platt, Tristan}

1997 The Sound of Light: Emergent Communication through Quechua Shamanic Dialogue. In: Rosaleen Howard-Malverde (ed.), Creating Context in Andean Cultures; pp. 196-226. Oxford: Oxford University Press. (Oxford Studies in Anthropological Linguistics 6.)

\section{Pulgar Vidal, Javier}

1996 Geografía del Perú: las ocho regiones naturales, la regionalización transversal, la sabiduría ecológica tradicional. Lima: PEISA.

\section{Ricard Lanata, Xavier}

2003 Trois mythes quechua. Amerindia 28: 251-273. < http://www.vjf.cnrs.fr/sedyl/amerindia/articles/pdf/A_28_12.pdf $>$ (accessed 11.07.2017).

2007 Ladrones de sombra: el universo religioso de los pastores del Ausangate (Andes surperuanos). Traducción [del francés] de Sandra Recarte. Lima: Instituto Francés de Estudios Andinos (IFEA); Cuzco: Centro de Estudios Regionales Andinos Bartolomé de Las Casas (CBC). (Travaux de l'Institut Français d'Études Andines 256; Centro de Estudios Regionales Andinos Bartolomé de Las Casas, Antropología 13.)

\section{Salazar Recio, Inocencio}

1972 Unión familiar y salud en el pueblo aymara. Allpanchis 4: 85-100.

\section{Sallnow, Michael J.}

1987 Pilgrims of the Andes. Regional Cults in Cusco. Washington D.C. and London: Smithsonian Institution Press.

\section{Sánchez Garrafa, Rodolfo}

2006 Apus de los cuatro suyos: construcción del mundo en los ciclos mitológicos de las deidades montaña. Tesis de doctorado: Universidad Nacional Mayor de San Marcos, Lima. < http://cybertesis.unmsm.edu.pe/handle/cybertesis/2749 > (accessed 11.07.2017).

\section{Tercero cathecismo y exposicion de la Doctrina Christiana, por sermones [1585]}

1985 In: Tercer Concilio Provincial de Lima (ed.), Doctrina Christiana y catecismo para instruccion de indios .... [and] Tercero Cathecismo ... [and other texts]; pp. 333-778. Facsímil del texto trilingüe. (Corpus Hispanorum de Pace, vol. 26-2.) Madrid: Consejo Superior de Investigaciones Científicas. [Internet: digitised copy of the John Carter Brown Library, USA: https://openlibrary.org/works/OL15435929W/Tercero_cathecismo_y_exposicion _de la doctrina_christiana_por_sermones (accessed 11.07.2017).] 
The Huarochirí Manuscript. A Testament of Ancient and Colonial Andean Religion [ca. 1608]

1991 Translation from the Quechua by Frank Salomon and George L. Urioste. Annotations and introductory essay by Frank Salomon. Transcription by George L. Urioste. Austin: University of Texas Press.

\section{Thomassen, Bjørn}

2009 The Uses and Meanings of Liminality. International Political Anthropology, vol. 2, no. 1: 5-27. Accessible via < http://international.politicalanthropology.org/ > (accessed 11.07.2017).

UNESCO

2011 Pilgrimage to the Sanctuary of the Lord of Qoyllurit'i. Intangible Cultural Heritage of Humanity. Paris: UNESCO - Section of Intangible Cultural Heritage, 2011. < http://www.unesco.org/culture/ich/en/RL/pilgrimage-to-thesanctuary-of-the-lord-of-qoylluriti-00567 $>$ [also see video, by National Institute of Culture, Lima, 2004] (accessed 11.07.2017).

\section{Valderrama Fernández, Ricardo and Carmen Escalante Gutiérrez}

1992 Normas de transcripción. In: Ricardo Valderrama Fernández and Carmen Escalante Gutiérrez (eds.), Nosotros los humanos - Ñuqanchik runakuna. Testimonio de los quechuas del siglo XX; pp. 241-245. Centro de Estudios Regionales Andinos "Bartolomé de Las Casas", Cuzco. (Biblioteca de la Tradición Oral Andina 12.)

\section{Van den Berg, Hans}

1985 Diccionario religioso aymara. Iquitos: Centro de Estudios Teológicos de la Amazonía (CETA); Puno: Instituto de Estudios Aymaras (IDEA).

Visita hecha a la provincia de Chucuito por Garci Diez de San Miguel en el año 1567

1964 Versión paleográfica: Waldemar Espinoza Soriano. Lima: Ediciones de la Casa de la Cultura del Perú. (Documentos Regionales para la Etnología y Etnohistoria Andina, tomo I.)

\section{Wrisley, Betsy}

1973 Interpretaciones populares de 'Espíritu Santo' en Bolivia. Allpanchis 5: 159166. 